\title{
Natural Hybrids \\ of Phytophthora nicotianae and Phytophthora cactorum Demonstrated by Isozyme Analysis and Random Amplified Polymorphic DNA
}

\author{
Willem A. Man in 't Veld, Wil J. Veenbaas-Rijks, Elena Ilieva, \\ Arthur W. A. M. de Cock, Peter J. M. Bonants, and Rob Pieters
}

\begin{abstract}
First, second, third, and sixth authors: Plant Protection Service, Department of Mycology, P.O. Box 9102, NL 6700 HC Wageningen, the Netherlands; third author: Plant Protection Institute, Kostinbröd 2230, Sofia, Bulgaria; fourth author: Centraalbureau voor Schimmelcultures, Yeast Division, Julianalaan 67, NL 2628 BC Delft, the Netherlands; and fifth author: Research Institute for Plant Protection (IPODLO), P.O. Box 9060, $6700 \mathrm{GW}$ Wageningen, the Netherlands.
\end{abstract}

Accepted for publication 4 June 1998.

\begin{abstract}
Man in 't Veld, W. A., Veenbaas-Rijks, W. J., Ilieva, E., de Cock, A. W. A. M., Bonants, P. J. M., and Pieters, R. 1998. Natural hybrids of Phytophthora nicotianae and $P$. cactorum demonstrated by isozyme analysis and random amplified polymorphic DNA. Phytopathology 88:922-929.

Three similar isolates of Phytophthora (Phytophthora sp-h) were obtained from diseased Spathiphyllum and Primula plants. Cultural characteristics did not fit any known description of Phytophthora species. The Phytophthora sp-h isolates are papillate, are homothallic, possess 80 to $86 \%$ amphigynous antheridia, and have a maximum temperature for growth of $36.5^{\circ} \mathrm{C}$. Isozyme analysis of the Phytophthora sp-h isolates revealed a three-banded pattern with malic enzyme and a three-banded pattern with malate dehydrogenase on the second putative locus. The fastest band at both enzyme loci comigrated with the single $P$. nicotianae band, the slowest band comigrated with the single $P$. cactorum (and also $P$. pseudotsugae)
\end{abstract}

ABSTRACT band, and one band in between was concluded to represent the heterodimeric isozyme. The random amplified polymorphic DNA patterns of the Phytophthora sp-h isolates almost exclusively consisted of bands that were also present in either $P$. nicotianae or P. cactorum. Southern hybridization showed that bands specific for $P$. nicotianae were present as comigrating bands in the Phytophthora sp-h isolates. The same was found for species-specific bands of $P$. cactorum. It is concluded that the three Phytophthora sp-h isolates represent interspecific hybrids, $P$. nicotianae being the one parent and P. cactorum the other. Analysis of mitochondrial DNA with restriction enzymes revealed banding patterns in all the Phytophthora sp-h isolates identical with those of $P$. nicotianae, confirming that indeed P. nicotianae was one of the parents.

Additional keywords: morphology.

The question of naturally occurring, interspecific hybrids of Phytophthora has been scarcely addressed in the literature (2,3). Probably because of their presumed atypical appearance, they are hard to detect and, moreover, they may be rare (2). Nevertheless, the question of hybridization in Phytophthora is important, since hybridization may be responsible for the introduction in nature of new variants in pathogen populations.

We have obtained three similar Phytophthora isolates (Phytophthora $\mathrm{sp}-\mathrm{h}$ ) from diseased Spathiphyllum and Primula plants grown in hydroponic systems. These systems facilitate physical encounters between different Phytophthora species, since in many greenhouses different crops are serviced by the same hydroponic source.

All three isolates have papillate sporangia, are homothallic, possess mainly amphigynous antheridia, and have a maximum growing temperature of $36.5^{\circ} \mathrm{C}$. Using the tabular key of Stamps et al. (25), they could not be assigned to a known Phytophthora species unambiguously.

Diseases caused by Phytophthora species are common in ornamentals grown in greenhouses in the Netherlands. In the last decades, 21 different Phytophthora species have been recorded altogether; two species were observed on Spathiphyllum (P. drechsleri and $P$. nicotianae) and three on Primula (P. nicotianae, P. palmivora, and $P$. primulae). Generally, these Phytophthora species cause severe root rot and blackening of stems of the host. The three homothallic Phytophthora sp-h isolates were obtained from diseased Spathiphyllum and Primula plants grown in hydroponic systems.

Symptoms caused by these isolates were identical to those caused by the Phytophthora species previously mentioned. In all three cases of Phytophthora sp-h, oospores were observed in the stems 
of all diseased plants. So far, observations from growers gave no indication that these isolates showed increased aggressiveness towards their respective hosts.

Preliminary experiments using isozyme analysis indicated that the three isolates of Phytophthora $\mathrm{sp}$-h might possibly represent hybrids of $P$. nicotianae van Breda de Haan and $P$. cactorum (Lebert \& Cohn) J. Schröter.

The purpose of this paper was to test the hypothesis that the three Phytophthora sp-h isolates concerned were hybrids, with $P$. nicotianae and $P$. cactorum as presumed parental species, by performing a comparative study of morphology, isozyme patterns, and Southern analysis of RAPD of most species of groups I and II.

\section{MATERIALS AND METHODS}

Fungal isolates and study of morphology. Fungal isolates and their sources are listed in Table 1. Cultures were maintained on cornmeal-agar slants. Isolates were cultivated on V8 agar at $20^{\circ} \mathrm{C}$ in the dark to study the morphological features (8). The formation of sporangia was stimulated by growing the mycelium, taken from the margin of V8 cultures, in the vicinity of pepper seeds in pond water. The dimensions of oogonia, oospores, and sporangia were measured. For all characteristics studied, at least 25 measurements were made for each isolate, and the average value was calculated. The attachment of the antheridia was only scored in clear situations.

The maximum growing temperature was determined by incubating the colonies at different temperatures $\left(31\right.$ to $\left.37^{\circ} \mathrm{C}\right)$ with intervals of $0.5^{\circ} \mathrm{C}$. The highest temperature at which growth occurred was considered to be the maximum growing temperature.
To be certain that the Phytophthora sp-h isolates do not represent a physical mixture of species, we established five strains by isolating zoospores from isolate PD 93/1339. Reisolates from artificially infected Spathiphyllum plants using PD 93/1339 and PD 94/1166 were labeled PD 93/1339-R' and PD 94/1166-R', respectively.

Isozyme analysis. Cultivation of mycelium. Isolates of all Phytophthora spp. were grown in $50 \mathrm{ml}$ of tryptone soy broth medium in 250-ml Erlenmeyer flasks on a rotary shaker at $40 \mathrm{rpm}$ in the dark. Each flask had been inoculated with three V8-agar discs (diameter $5 \mathrm{~mm}$ ) with mycelium taken from actively growing colony margins of cultures ( 3 days old). Cultures were incubated at $23^{\circ} \mathrm{C}$. After 7 days, the mycelium of each isolate was collected by sieving, after which the tissue was dried by pressing between filter paper. The mycelium was stored overnight at $-20^{\circ} \mathrm{C}$ before extraction of enzymes.

Enzyme extraction. Frozen mycelium was thawed at $4^{\circ} \mathrm{C}$ for $3 \mathrm{~h}$ before enzyme extraction. Routinely, about $0.5 \mathrm{~g}$ of mycelium was ground in a chilled mortar with sand and $70 \mu \mathrm{l}$ of extraction medium. The extraction medium consisted of $0.1 \mathrm{M}$ Tris- $\mathrm{HCl}(\mathrm{pH} 7.0)$, $1 \mathrm{mM}$ dithiothreitol, $50 \mathrm{mM}$ EDTA, $10 \%$ polyvinylpyrrolidone (wt/ vol), $50 \mu \mathrm{g}$ of soybean trypsin inhibitor per ml, $0.1 \mathrm{mM}$ phenylmethylsulfonyl fluoride, and 5\% glycerol (vol/vol). All mycelia were ground for $3 \mathrm{~min}$. The homogenate was transferred to Eppendorf tubes and centrifuged for $10 \mathrm{~min}$ at $16,000 \times g\left(4^{\circ} \mathrm{C}\right)$. The supernatant $(40$ to $80 \mu \mathrm{l})$ was collected and stored at $-70^{\circ} \mathrm{C}$ before use.

Electrophoresis and enzyme staining. Electrophoresis was carried out at $4^{\circ} \mathrm{C}$ using the automated PhastSystem of Pharmacia (Roosendaal, the Netherlands). Crude extracts, obtained as described before, were routinely analyzed for malic enzyme (MDHP; EC 1.1.1.40)

TABLE 1. Isolates of Phytophthora used in this study, their origins (host plant and location), reference numbers, and biochemical methods of analysis

\begin{tabular}{|c|c|c|c|c|c|c|c|}
\hline \multirow[b]{2}{*}{ Phytophthora species } & \multirow[b]{2}{*}{ Group } & \multirow[b]{2}{*}{ Host plant } & \multirow[b]{2}{*}{ Location } & \multirow[b]{2}{*}{ Isolate number ${ }^{\mathrm{a}}$} & \multicolumn{3}{|c|}{ Methods of analysis ${ }^{\mathrm{b}}$} \\
\hline & & & & & Isozymes & $\mathrm{RAPD}^{\mathrm{c}}$ & $\mathrm{mtDNA}^{\mathrm{d}}$ \\
\hline P. cactorum & I & Cactus & Unknown & CBS 108.09 & - & + & + \\
\hline P. cactorum & I & Prunus armeniaca & India & CBS 279.37 & - & - & + \\
\hline P. cactorum & I & Rubus idaeus & New York (USA) & P6183 & + & + & + \\
\hline P. cactorum & $\mathrm{I}$ & Panax quinquefolius & Wisconsin (USA) & P1943 & + & - & - \\
\hline P. cactorum & $\mathrm{I}$ & Fragaria $\times$ ananassa & New York (USA) & P6187 & + & + & + \\
\hline P. clandestina & $\mathrm{I}$ & Trifolium subterraneum & Victoria (Australia) & CBS 347.86 & - & + & - \\
\hline P. idaei & $\mathrm{I}$ & Rubus idaeus & Great Britain & CBS $971.95^{*}$ & + & + & - \\
\hline P. iranica & $\mathrm{I}$ & Solanum melongena & Iran & CBS $374.72 *$ & + & + & - \\
\hline P. pseudotsugae & $\mathrm{I}$ & Pseudotsuga menziesii & Oregon (USA) & CBS $444.84^{*}$ & + & + & - \\
\hline P. tentaculata & I & Chrysanthemum frutescens & Germany & CBS 412.96 & - & + & - \\
\hline P. boehmeriae & II & Boehmeria nivea & Japan & CBS 291.29 & - & + & - \\
\hline P. botryosa & II & Hevea brasiliensis & Malaysia & CBS 581.69 & - & + & - \\
\hline P. capsici & II & Capsicum аппиит & New Mexico (USA) & CBS $128.23^{*}$ & - & + & - \\
\hline P. citrophthora & II & Citrus sp. & California (USA) & CBS 950.87 & - & + & - \\
\hline P. heveae & II & Hevea brasiliensis & Malaysia & CBS 296.29 & - & + & - \\
\hline P. infestans & II & Solanum tuberosum & The Netherlands & CBS 366.51 & - & + & - \\
\hline P. katsurae & II & Soil & Taiwan & CBS 587.85 & - & + & - \\
\hline P. meadii & II & Hevea brasiliensis & India & CBS 219.88 & - & + & - \\
\hline P. megakarya & II & Theobroma cacao & Cameroon & CBS 238.83 & - & + & - \\
\hline P. nicotianae & II & Nicotiana tabacum & Puerto Rico & CBS 303.29 & - & - & + \\
\hline P. nicotianae & II & Nicotiana tabacum & Taiwan & CBS 305.29 & - & + & + \\
\hline P. nicotianae & II & Nicotiana tabacum & North Carolina (USA) & CBS 310.62 & + & - & - \\
\hline P. nicotianae & II & Nicotiana tabacum & Kentucky (USA) & P582 & + & + & + \\
\hline P. nicotianae & II & Nicotiana tabacum & Australia & P1753 & + & + & + \\
\hline P. nicotianae & II & Nicotiana tabacum & North Carolina (USA) & P1349 & + & - & - \\
\hline P. nicotianae & II & Vanilla planifolia & French Polynesia & P1923 & + & - & - \\
\hline P. nicotianae & II & Spathiphyllum sp. & The Netherlands & PD 96/4943 & - & + & - \\
\hline P. palmivora & II & Theobroma cacao & Trinidad & CBS 298.29 & - & + & - \\
\hline Phytophthora $\mathrm{sp}-\mathrm{h}$ & & Spathiphyllum sp. & The Netherlands & PD 93/1339 & + & + & + \\
\hline Phytophthora $\mathrm{sp}-\mathrm{h}$ & & Spathiphyllum sp. & The Netherlands & PD 93/1339-MZ & + & + & - \\
\hline Phytophthora $\mathrm{sp}-\mathrm{h}$ & & Spathiphyllum sp. & The Netherlands & PD 93/1339-R' & + & - & - \\
\hline Phytophthora $\mathrm{sp}-\mathrm{h}$ & & Primula sp. & The Netherlands & PD 94/988 & + & + & + \\
\hline Phytophthora $\mathrm{sp}-\mathrm{h}$ & & Spathiphyllum sp. & The Netherlands & PD 94/1166 & + & + & + \\
\hline Phytophthora $\mathrm{sp}-\mathrm{h}$ & & Spathiphyllum sp. & The Netherlands & PD 94/1166-R' & + & - & - \\
\hline
\end{tabular}

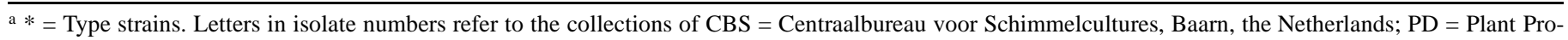
tection Service, Wageningen, the Netherlands; and P = University of California, Riverside, CA.

$\mathrm{b}+=$ analyzed, and $-=$ not analyzed.

c Random amplified polymorphic DNA.

d Mitochondrial DNA. 
on native, $12.5 \%$ homogeneous polyacrylamide gels and for malate dehydrogenase (MDH; EC 1.1.1.37) on native, 8 to $25 \%$ gradient polyacrylamide gels. The gels were made with $0.11 \mathrm{M}$ Tris-acetate buffer ( $\mathrm{pH}$ 6.4). The running buffer, contained in $2 \%$ agarose gel, consisted of a $0.25 \mathrm{M}$ Tris and $0.88 \mathrm{M}$ L-alanine buffer (pH 8.8). Glycine was added to the samples to a final concentration of $0.22 \mathrm{M}$. Extracts assayed for MDH activity had to be diluted 5 to 10 times to avoid smearing.

At the completion of electrophoresis, gels were immersed in freshly prepared staining solutions in the dark at $37^{\circ} \mathrm{C}$ for 5 and $20 \mathrm{~min}$ for MDH and MDHP, respectively.

Two enzymatic stains tested, notably those for MDH and MDHP, gave clearly interpretable bands. The reaction ingredients for each enzyme were as follows. MDH contained $25 \mathrm{ml}$ of $0.2 \mathrm{M}$ Tris- $\mathrm{HCl}$, $\mathrm{pH} 8.0 ; 440 \mathrm{mg}$ of L-malic acid (disodium salt); $12.5 \mathrm{mg}$ of NAD; $7.5 \mathrm{mg}$ of nitroblue tetrazolium (NBT) (N 6876; Sigma Chemical Co., Zwijndrecht, the Netherlands); and $1 \mathrm{mg}$ of phenazine methyl sulfate (PMS) (P9625; Sigma Chemical Co.). MDHP contained $25 \mathrm{ml}$ of $0.2 \mathrm{M}$ Tris-HCl, $\mathrm{pH} 8.0 ; 440 \mathrm{mg}$ of L-malic acid (disodium salt); $12.5 \mathrm{mg}$ of NADP; $7.5 \mathrm{mg}$ of NBT; and $1 \mathrm{mg}$ of PMS.

Alleles were scored according to the method of Spielman et al. (24). Arbitrarily, one allele was designated 100, and other alleles were numbered according to their mobilities relative to this allele. Since Phytophthora spp. are diploid, two identical numbers were assigned to one band. A three-banded pattern was interpreted as the product of two different alleles encoding for a dimeric enzyme (21). Both MDH (15) and MDHP (18) are known to be dimeric enzymes in Phytophthora spp. When two zones of activity were present on the gel, the slowest zone was assigned the first locus and the fastest zone the second locus.

Analysis of RAPD. Cultivation of mycelium for DNA isolation. Fungal isolates were grown in pea broth medium (filtered decoction of $200 \mathrm{~g}$ of frozen peas boiled in 1 liter of distilled water for $1 \mathrm{~h}$, to which $5 \mathrm{~g}$ of glucose was added) in petri dishes for 5 to 10 days at $25^{\circ} \mathrm{C}$ in the dark. Mycelia were harvested by vacuum-filtration, washed twice with distilled water, frozen at $-20^{\circ} \mathrm{C}$, and freezedried overnight. Dry mycelia were stored at $-20^{\circ} \mathrm{C}$ when not used immediately.

Isolation of DNA. DNA was extracted after the method of Möller et al. (16) with slight modifications (13). Freeze-dried mycelium (30 mg) was extracted in $1 \mathrm{ml}$ of TES buffer (100 mM Tris- $\mathrm{HCl}$, $25 \mathrm{mM}$ EDTA, and $2 \%$ sodium dodecyl sulfate [SDS], $\mathrm{pH}$ 8.0) with 100 to $200 \mu \mathrm{g}$ of proteinase $\mathrm{K}$ at $55^{\circ} \mathrm{C}$ for $30 \mathrm{~min}$ with mixing at 5 -min intervals. After adding $\mathrm{NaCl}(280 \mu \mathrm{l}, 5 \mathrm{M})$ and $138 \mu \mathrm{l}$ of cetyltrimethylammonium bromide/ $\mathrm{NaCl}(10 \% / 0.7 \mathrm{M})$, the mixture was incubated for $10 \mathrm{~min}$ at $65^{\circ} \mathrm{C}$. The suspension was centrifuged $(16,000 \times g)$ for $10 \mathrm{~min}$ at $4^{\circ} \mathrm{C}$ to remove cell debris. One milliliter of supernatant was extracted with an equal volume of chloroform/ isoamyl alcohol $(24: 1)$ for $30 \mathrm{~min}$ on ice, centrifuged $(16,000 \times g)$ for $10 \mathrm{~min}$ at $4^{\circ} \mathrm{C}$, and the supernatant was extracted again by adding $450 \mu \mathrm{l}$ of $5 \mathrm{M}$ ammonium acetate and incubating for 30 $\min$ on ice. The mixture was centrifuged at $16,000 \times g$ for $10 \mathrm{~min}$ at $4^{\circ} \mathrm{C}$. DNA was precipitated from $1,300 \mu$ of the supernatant by adding $715 \mu \mathrm{l}$ of isopropanol. The solution was centrifuged at $16,000 \times g$ for $15 \mathrm{~min}$, and the DNA pellet was washed for $15 \mathrm{~min}$ with $800 \mu \mathrm{l}$ of $70 \%$ ethanol at ambient temperature. The pellet was dried and dissolved in $100 \mu \mathrm{l}$ of TE buffer $(10 \mathrm{mM}$ Tris-HCl and $1 \mathrm{mM}$ EDTA, $\mathrm{pH}$ 8.0).

Polymerase chain reaction (PCR). PCR was performed in $50-\mu \mathrm{l}$ volumes containing $10 \mathrm{mM}$ Tris- $\mathrm{HCl}(\mathrm{pH} 9.5), 50 \mathrm{mM} \mathrm{KCl}, 1.5 \mathrm{mM}$ $\mathrm{MgCl}_{2}, 0.01 \%$ gelatin, $200 \mu \mathrm{M}$ of each deoxy-nucleotide triphosphate, 10 pmol of a single primer, and $0.5 \mathrm{U}$ of Thermus thermophilus DNA polymerase (Super Taq; Sphaero Q, Leiden, the Netherlands). Primers tested for RAPD were (i) random 10-mer primers (each of the 20 random primers of kit A of Operon Technologies, Inc., Alameda, CA) and (ii) 15-mer primer ((ATG) $)_{5}$ and the core sequence of M13 [GAGGGTGGCGGTTCT]) (26). Template DNA consisted of $50 \mathrm{ng}$ of a crude nucleic acid extract pre- pared as described above. In the case of 10-mer primers, 40 amplification cycles of $1 \mathrm{~min}$ at $94^{\circ} \mathrm{C}, 1 \mathrm{~min}$ at $34^{\circ} \mathrm{C}$, and $2 \mathrm{~min}$ at $72^{\circ} \mathrm{C}$ were performed in a Biomed thermocycler (type 60; Biomed, Theres, Germany). For 15-mer primers, conditions were the same, except that denaturing was $20 \mathrm{~s}$ at $94^{\circ} \mathrm{C}$ and annealing was $1 \mathrm{~min}$ at $48^{\circ} \mathrm{C}$.

Southern blot/probe/hybridization. Southern blot. For Southern blot analysis (23), $1 \mu \mathrm{l}$ of each RAPD reaction mixture was run on $1.7 \%$ agarose gel in TAE buffer $(40 \mathrm{mM}$ Tris- $\mathrm{HCl}$ and $2 \mathrm{mM}$ EDTA, $\mathrm{pH} 8.0$ ) at $4 \mathrm{~V} / \mathrm{cm}$ for $3 \mathrm{~h}$. Bands were visualized with ethidium bromide $(0.5 \mu \mathrm{g} / \mathrm{ml})$ and photographed under 302-nm light. After electrophoresis, gels were rinsed for $10 \mathrm{~min}$ with $0.25 \mathrm{~N} \mathrm{HCl}$, two times for $15 \mathrm{~min}$ with denaturation buffer $(0.5 \mathrm{~N} \mathrm{NaOH}$ and $1.5 \mathrm{M} \mathrm{NaCl})$, and finally two times for $15 \mathrm{~min}$ with neutralization buffer (0.5 M Tris-HCl, pH 7.5, and $1.5 \mathrm{M} \mathrm{NaCl})$. Fragments were blotted onto Hybond N (Amersham, 's-Hertogenbosch, the Netherlands) overnight with $20 \times \mathrm{SSC}(1 \times \mathrm{SSC}$ is $0.15 \mathrm{M} \mathrm{NaCl}$ plus $0.015 \mathrm{M}$ sodium citrate). After blotting, blots were rinsed with $2 \times \mathrm{SSC}$ and dried. Finally, the blots were heated for $2 \mathrm{~h}$ at $80^{\circ} \mathrm{C}$.

Probe. To prove that RAPD bands present in Phytophthora $\mathrm{sp}-\mathrm{h}$ that comigrate with bands specific for $P$. nicotianae and $P$. cactorum contain identical sequences, fragments were excised from RAPD gels and incubated overnight with $50 \mu \mathrm{l}$ of TE buffer, $\mathrm{pH}$ 8.0. One microliter of the supernatant was reamplified with RAPD primer (described above).

The reamplification mixture ( 2 to $3 \mu \mathrm{l}$ ) was random prime-labeled with ${ }^{32} \mathrm{P}-\mathrm{dATP}$ (random prime labeling kit of Boehringer $\mathrm{GmbH}$, Mannheim, Germany). Labeled probe was separated from free ${ }^{32}$ P-dATP using Sephadex G-50 column chromatography.

Hybridization. Blots were hybridized with labeled probe overnight at $65^{\circ} \mathrm{C}$ in hybridization buffer $(5 \times$ SSPE $[1 \times$ SSPE is $0.18 \mathrm{M}$ $\mathrm{NaCl}, 10 \mathrm{mM} \mathrm{NaPO}_{4}$, and $1 \mathrm{mM}$ EDTA, pH 7.7], 5× Denhardt's solution, $0.1 \%$ SDS, and $20 \mu \mathrm{g}$ of salm sperm DNA per ml).

After hybridization, blots were washed twice with $2 \times$ SSPE and $0.1 \%$ SDS at room temperature for $10 \mathrm{~min}$ and with $1 \times$ SSPE and $0.1 \% \mathrm{SDS}$ at $65^{\circ} \mathrm{C}$ for $15 \mathrm{~min}$. Finally, blots were exposed to KODAK X-OMAT AR films (Kodak, Drieborgen, the Netherlands) at $-70^{\circ} \mathrm{C}$. Blots were stripped with $0.2 \mathrm{~N} \mathrm{NaOH}$ and $0.1 \%$ SDS at $37^{\circ} \mathrm{C}$ for probing again.

Analysis of mtDNA. Isolation of $m t D N A$. For DNA isolation, isolates were grown and harvested as described above for RAPD analysis. The mycelium was freeze-dried, and $5 \mathrm{~g}$ of fresh weight was finely ground with sand in a mortar with a pestle for $1 \mathrm{~h}$ and then incubated in $25 \mathrm{ml}$ of TES buffer containing $0.5 \mathrm{mg}$ of proteinase $\mathrm{K}$ at $55^{\circ} \mathrm{C}$. The suspension was then extracted with $15 \mathrm{ml}$ of chloroform/isoamyl alcohol $(24: 1, \mathrm{vol} / \mathrm{vol})$, cooled on ice for at least $15 \mathrm{~min}$, and centrifuged at $4^{\circ} \mathrm{C}$ at $100,000 \times g$ for $45 \mathrm{~min}$. The supernatant was then centrifuged at $4^{\circ} \mathrm{C}$ at $100,000 \times g$ for $45 \mathrm{~min}$ to remove polysaccharides. DNA in the supernatant was precipitated with $1 / 50$ volume of $5 \mathrm{M} \mathrm{NaCl}$ and one volume of isopropanol for $1 \mathrm{~h}$ at room temperature, followed by centrifugation $(3,200 \times g)$ for $15 \mathrm{~min}$ at $20^{\circ} \mathrm{C}$. Pellets were washed with $10 \mathrm{ml}$ of $70 \%$ ethanol, dried, and dissolved in $8 \mathrm{ml}$ of TE buffer. Finally, $8.8 \mathrm{~g}$ of CsCL and $60 \mu \mathrm{l}$ of bisbenzimide (Hoechst 33258; Hoechst, Amsterdam; stock solution $1 \mathrm{mg} / \mathrm{ml}$ ) were added to the DNA-containing solution that was then centrifuged at $135,000 \times g$ at $20^{\circ} \mathrm{C}$ for $40 \mathrm{~h}$. Of the resulting two fluorescent bands, the upper one, containing the mtDNA, was collected, and bisbenzimide was removed by extraction with isopropanol saturated with $\mathrm{CsCl} / \mathrm{TE}$ buffer. After dialysis against 2 liters of TE buffer overnight at room temperature, the DNA was precipitated with $\mathrm{NaCl} /$ propanol, washed with $70 \%$ ethanol, dried, and dissolved in TE buffer (17).

Restriction enzyme analysis. To see which mtDNA was inherited in the Phytophthora sp-h isolates, preparations of mtDNA were digested with HaeIII, ScrfI, and HindII according to the instructions of the supplier (Boehringer $\mathrm{GmbH}$ ). Digested mtDNAs were analyzed by electrophoresis in $1 \%$ agarose gels prepared in TAE buffer at $2 \mathrm{~V} / \mathrm{cm}$ for $15 \mathrm{~h}$, stained with ethidium bromide $(0.5 \mu \mathrm{g} /$ $\mathrm{ml}$ ), and photographed in 302-nm light. 

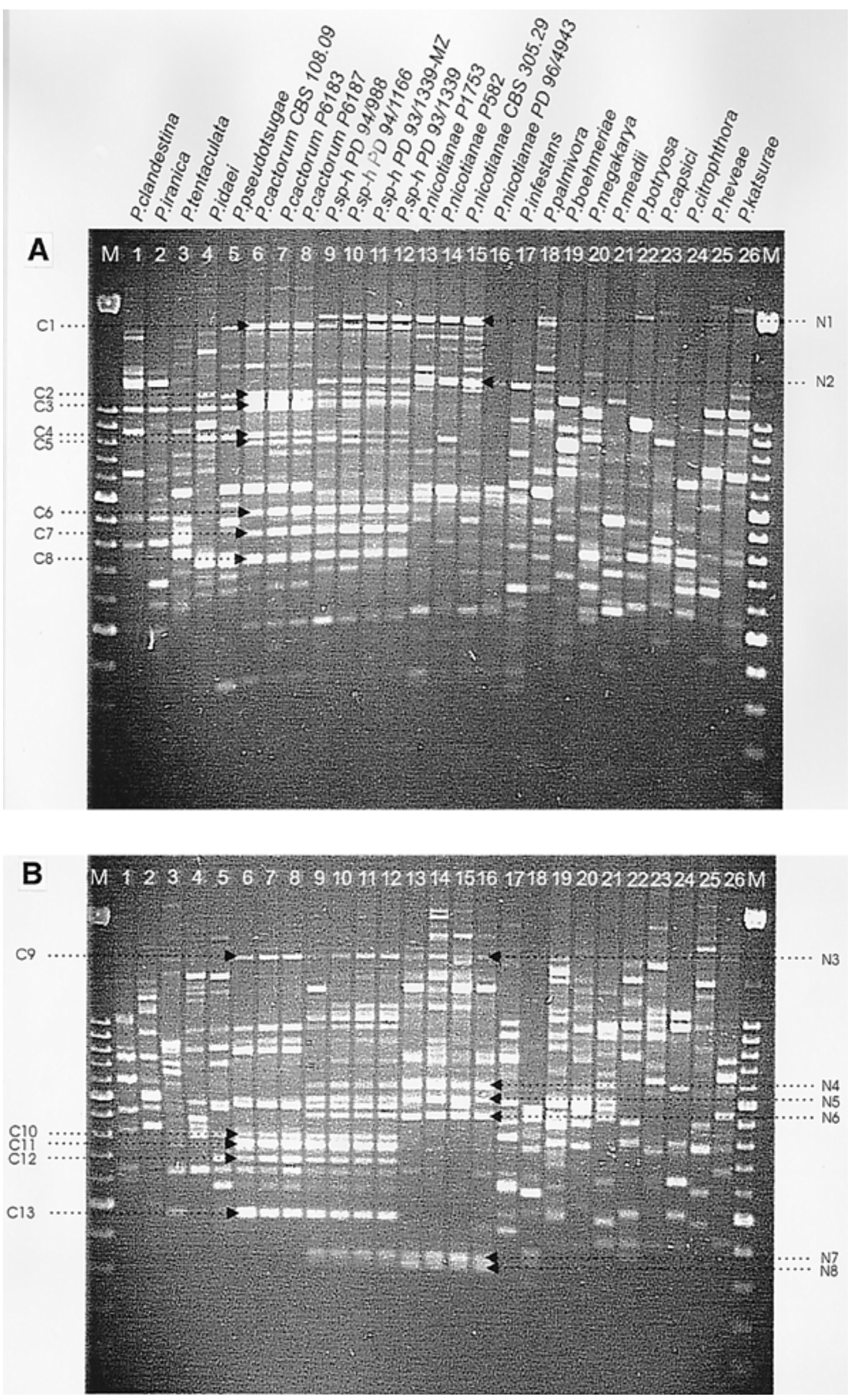

Fig. 1. Random amplified polymorphic DNA banding patterns of Phytophthora isolates belonging to group I and group II with A, primer M13 and B, OPA 13 (reference isolate numbers shown in Table 1). 


\section{RESULTS}

Characterization of single-zoospore progeny. We established five strains by isolating single zoospores of PD 93/1339. The RAPD patterns of PD 93/1339-MZ were identical to those of isolate PD 93/1339, from which the zoospores originated (Fig. 1A and B). All five monozoosporic isolates of PD 93/1339 generated isozyme patterns that were identical to those of the isolate PD 93/1339, from which the zoospores originated (Fig. 2A and B, lanes 8 and 9). This confirmed that isolate PD 93/1339 was not a physical mixture.

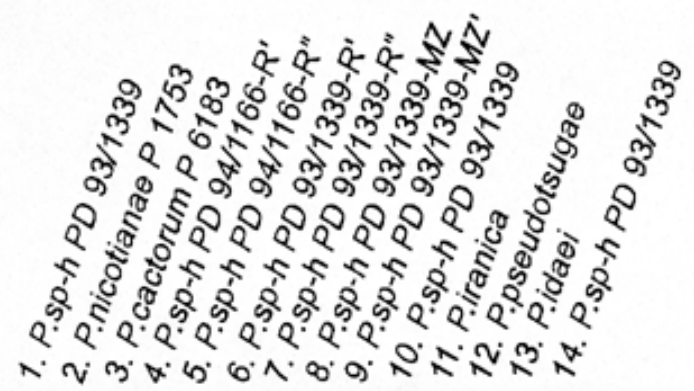

A

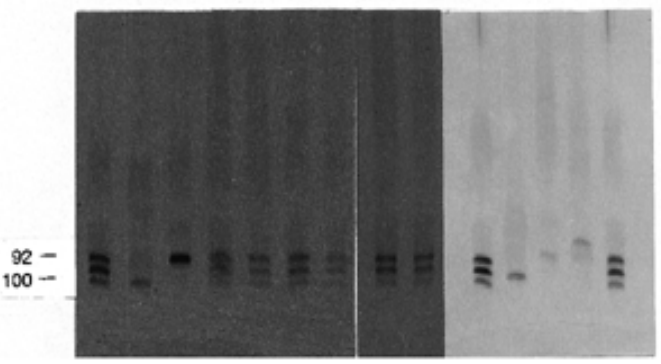

B

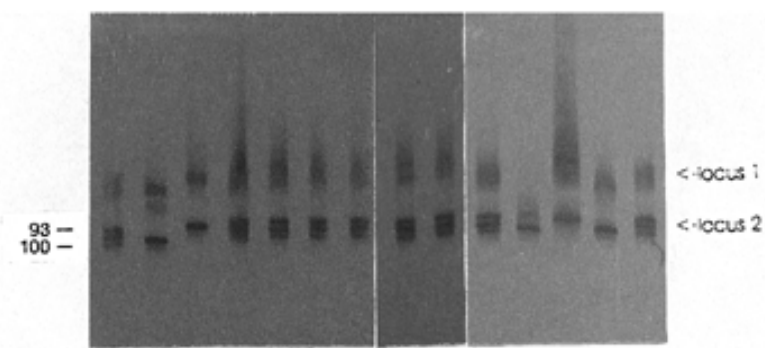

Fig. 2. A, Malic enzyme (MDHP) patterns and $\mathbf{B}$, malate dehydrogenase (MDH) patterns generated in several Phytophthora strains (assigned genotypes shown in Table 2).
Isozyme analysis. Isozyme analysis of MDHP showed a single band in the isolates of $P$. cactorum, $P$. idaei, $P$. iranica, $P$. pseudotsugae (all group I species), and $P$. nicotianae. The single $P$. pseudotsugae band comigrated with that of P. cactorum (Fig. 2A, Table 2). All three isolates of Phytophthora sp-h showed three MDHP bands, the upper one comigrating with $P$. cactorum and $P$. pseudotsugae, and the lower one comigrating with $P$. nicotianae and one intermediate band. The single $P$. nicotianae band was assigned $M d h p^{100}$, and all other bands were calculated relative to this band.

Oudemans and Coffey (20) assigned the MDH enzyme bands they found in P. nicotianae on starch gels to two different putative loci. The first locus $(M d h-1)$ was of heterogeneous composition, whereas $M d h-2$ consisted of one band in P. nicotianae. We found that, on native polyacrylamide gels, only the second locus could be resolved; the bands belonging to the first locus formed a long smear (Fig. 2B). In P. cactorum, the first putative locus also could not be analyzed in our system, due to smearing. Therefore, only the second MDH locus was analyzed.

Isozyme analysis of $M d h-2$ showed a single band in the isolates of $P$. idaei, $P$. nicotianae, $P$. cactorum, and $P$. pseudotsugae with unique migration distance, except for $P$. pseudotsugae, which comigrated with $P$. cactorum. $P$. iranica generated a three-banded pattern with unique migration distances, the upper band being very faint indeed (Fig. 2B). In Phytophthora sp-h isolates, three bands were found also at $M d h-2$, the upper one comigrating with $P$. cactorum and $P$. pseudotsugae, and the lower one comigrating with $P$. nicotianae and one band in between (Fig. 2B). The single $P$. nicotianae band was assigned $M d h-2^{100}$, and all other bands were calculated relative to this band.

RAPD. The RAPD patterns of isolates of Phytophthora sp-h and their putative parents ( $P$. cactorum and $P$. nicotianae) as well as most other papillate species generated with primers M13 coresequence and OPA 13 are shown in Figure 1A and B, respectively. All isolates of $P$. nicotianae showed almost identical banding patterns of PCR products with the two primers used (PD 96/4943 reacted poorly with primer M13); the same was found for all strains of $P$. cactorum. Patterns of different species, however, differed considerably from each other, showing only few, if any, common bands, except for some species in group I. P. pseudotsugae and, to a lesser degree, $P$. idae $i$ shared some bands with $P$. cactorum. The three Phytophthora sp-h strains showed almost identical patterns. Bands in these patterns comigrated with species-specific bands of $P$. nicotianae $\left(\mathrm{N}_{1}\right.$ to $\left.\mathrm{N}_{8}\right)$ on the one hand and speciesspecific bands of $P$. cactorum $\left(\mathrm{C}_{1}\right.$ to $\left.\mathrm{C}_{13}\right)$ on the other (Fig. 1A and B). Actually, patterns of Phytophthora sp-h almost exclusively consisted of bands also present in either $P$. cactorum or $P$. nicotianae. This was confirmed by the results of most of the other primers used (some primers did not perform well).

TABLE 2. Features of Phytophthora sp-h, P. cactorum, P. idaei, P. iranica, P. nicotianae, and P. pseudotsugae isolates

\begin{tabular}{|c|c|c|c|c|c|c|c|c|c|c|c|c|}
\hline \multirow[b]{2}{*}{ Species, isolate } & \multicolumn{2}{|c|}{$\begin{array}{c}\text { Oogonia } \\
\text { dimensions }(\mu \mathrm{m})\end{array}$} & \multicolumn{2}{|c|}{$\begin{array}{c}\text { Oospore } \\
\text { dimensions }(\mu \mathrm{m})\end{array}$} & \multicolumn{2}{|c|}{$\begin{array}{c}\text { Sporangia } \\
\text { length/breadth }(\mu \mathrm{m})\end{array}$} & \multirow{2}{*}{$\begin{array}{l}\text { Length/ } \\
\text { breadth } \\
\text { ratio }\end{array}$} & \multirow{2}{*}{$\begin{array}{c}\text { Amphigynous } \\
\text { antheridia }\end{array}$} & \multirow{2}{*}{$\begin{array}{l}\text { Sexual } \\
\text { type }\end{array}$} & \multirow{2}{*}{$\begin{array}{l}\text { Maximum } \\
\text { growing } \\
\text { temp. }\left({ }^{\circ} \mathrm{C}\right)\end{array}$} & \multicolumn{2}{|c|}{ Genotype } \\
\hline & Range & Average & Range & Average & Range & Average & & & & & Mdhp & $M d h-2$ \\
\hline P. idaei, CBS $971.95^{\mathrm{a}}$ & $27-38$ & 32.1 & $23-31$ & 27.0 & $41-55 \times 30-44$ & $48.9 \times 34.4$ & $1.35: 1$ & $\sim 0 \%$ & Homothallic & 27.0 & $87 / 87$ & $99 / 99$ \\
\hline P. iranica, CBS $374.72^{\mathrm{b}}$ & $21-45$ & 34.0 & $15-37$ & 29.3 & $30-72 \times 22-51$ & $47.9 \times 36.8$ & $1.30: 1$ & $\sim 0 \%$ & Homothallic & 35.0 & $98 / 98$ & $87 / 97$ \\
\hline P. pseudotsugae, CBS $444.84^{\mathrm{c}}$ & $24-45$ & 35.0 & $27-33$ & 24.0 & $34-45 \times 28-35$ & $39.0 \times 32.0$ & $1.23: 1$ & $\sim 0 \%$ & Homothallic & 30.0 & $92 / 92$ & $93 / 93$ \\
\hline P. cactorum $^{\mathrm{d}}$ & $23-35$ & 27.4 & $18-27$ & 24.0 & $24-55 \times 19-40$ & $35.7 \times 26.8$ & $1.33: 1$ & $0 \%$ & Homothallic & 32.0 & & \\
\hline P. cactorum, $\mathrm{P} 6183$ & $25-30$ & 27.8 & $22-25$ & 23.6 & $35-40 \times 26-30$ & $36.6 \times 28.0$ & $1.31: 1$ & $0 \%$ & Homothallic & 32.0 & $92 / 92$ & $93 / 93$ \\
\hline Phytophthora sp-h, PD 93/1339 & $34-38$ & 35.8 & $29-32$ & 31.0 & $30-52 \times 23-40$ & $42.7 \times 33.1$ & $1.29: 1$ & $84 \%$ & Homothallic & 36.5 & $92 / 100$ & $93 / 100$ \\
\hline Phytophthora sp-h, PD 94/988 & $34-40$ & 36.1 & $28-34$ & 30.7 & $36-48 \times 29-38$ & $41.3 \times 32.8$ & $1.26: 1$ & $86 \%$ & Homothallic & 36.5 & $92 / 100$ & $93 / 100$ \\
\hline Phytophthora sp-h, PD 94/1166 & $34-38$ & 35.7 & $30-34$ & 31.8 & $34-46 \times 30-36$ & $41.0 \times 32.9$ & $1.25: 1$ & $80 \%$ & Homothallic & 36.5 & $92 / 100$ & $93 / 100$ \\
\hline P. nicotianae, $\mathrm{P} 582$ & $24-30$ & 26.7 & $22-26$ & 23.4 & $29-54 \times 25-39$ & $43.1 \times 31.4$ & $1.37: 1$ & $100 \%$ & Heterothallic & 36.5 & $100 / 100$ & $100 / 100$ \\
\hline P. nicotianae $e^{\mathrm{d}}$ & $25-41$ & 31.8 & $20-31$ & 26.7 & $23-79 \times 16-54$ & $43.9 \times 33.0$ & $1.33: 1$ & $100 \%$ & Heterothallic & 36.0 & & \\
\hline
\end{tabular}

${ }^{a}$ General features according to the description of Kennedy and Duncan (12) (except isozyme genotypes).

${ }^{\mathrm{b}}$ General features according to the description of Ershad (7), except isozyme genotypes.

c General features according to the description of Hamm and Hansen (11), except isozyme genotypes.

${ }^{\mathrm{d}}$ General features according to the description of Kröber (14). 
Southern blot/hybridization. To prove unambiguously the homologous nature of comigrating bands, bands were excised from RAPD gels and used as probes on a Southern blot from these RAPD gels. Figure 3 shows the hybridization patterns of the Southern blot of the RAPD gel (primer M13) hybridized with band $\mathrm{C}_{7}$ (Fig. 3A) and $\mathrm{N}_{2}$ (Fig. 3B) and the hybridization patterns of the Southern blot of the RAPD gel (primer OPA 13) hybridized with band $\mathrm{C}_{13}$ (Fig. 3C) and $\mathrm{N}_{4}$ (Fig. 3D). All four hybridization patterns show the presence of both unique $P$. cactorum or $P$. nicotianae sequences in the Phytophthora sp-h strains. All other species did not hybridize with any of the four probes used, except $P$. idaei, which hybridized weakly with $\mathrm{C}_{7}$ at a different position on the gel, and P. pseudotsugae, which hybridized weakly with $\mathrm{C}_{7}$ and $\mathrm{C}_{13}$ at different positions on the gel.

Characterization of mtDNA. In Figure 4, restriction enzyme patterns are shown generated in mtDNA from $P$. nicotianae, $P$. cactorum, and Phytophthora sp-h. With three restriction enzymes, HaeIII (data not shown), HindII (Fig. 4A), and ScrfI (Fig. 4B), the patterns in all three Phytophthora sp-h isolates were identical to those of $P$. nicotianae.

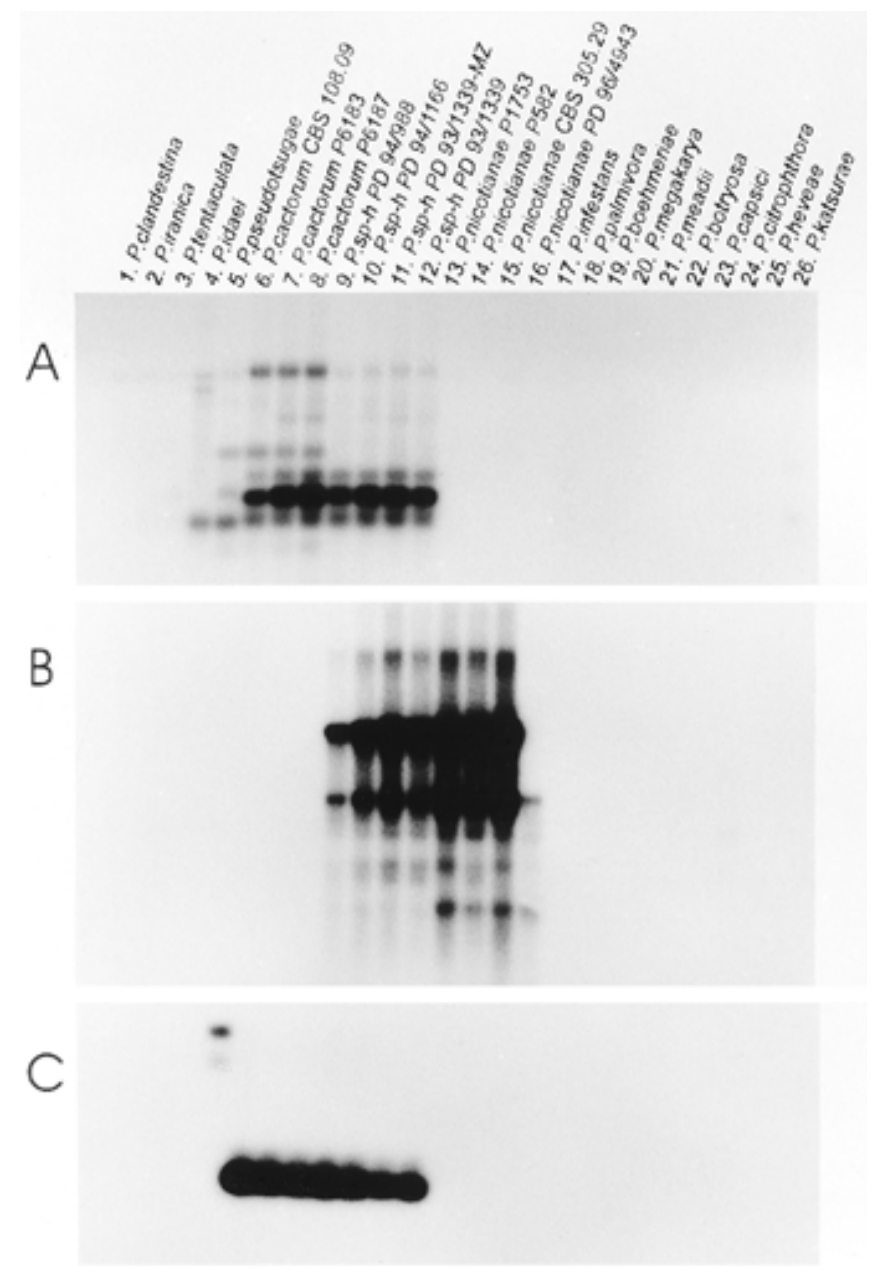

Fig. 3. Hybridization patterns of blot RAPD/M13 probed with $\mathbf{A}, \mathrm{C}_{7}$ and $\mathbf{B}$, $\mathrm{N}_{2}$ and blot RAPD/OPA 13 probed with $\mathbf{C}, \mathrm{C}_{13}$ and $\mathbf{D}, \mathrm{N}_{4}$.
Morphology. The cultural characters of the three Phytophthora sp-h strains, some group I species, and $P$. nicotianae are displayed in Table 2. The three Phytophthora sp-h strains are papillate, are homothallic, have predominantly amphigynous antheridia, and have a maximum temperature for growth of $36.5^{\circ} \mathrm{C}$.

Dimensions of oogonia, oospores, and sporangia of $P$. nicotianae (P582) and P. cactorum (P6183) were comparable to those determined by Kröber (14), although dimensions from his isolates were somewhat larger.

\section{DISCUSSION}

The RAPD patterns of the three Phytophthora sp-h strains seemed almost exclusively to represent the sum of the patterns of $P$. nicotianae and $P$. cactorum, although $P$. idaei and $P$. pseudotsugae showed some comigrating bands with both $P$. cactorum and the Phytophthora sp-h strains as well (Fig. 1A and B). However, Southern analysis showed that the three strains of Phytophthora sp-h indeed had a hybrid origin, with $P$. nicotianae the one parent and $P$. cactorum the other.

Hybrids of $P$. nicotianae and $P$. cactorum should have the $M d h p^{100}$ and $M d h-2^{100}$ alleles of P. nicotianae and the $M d h p^{92}$ and

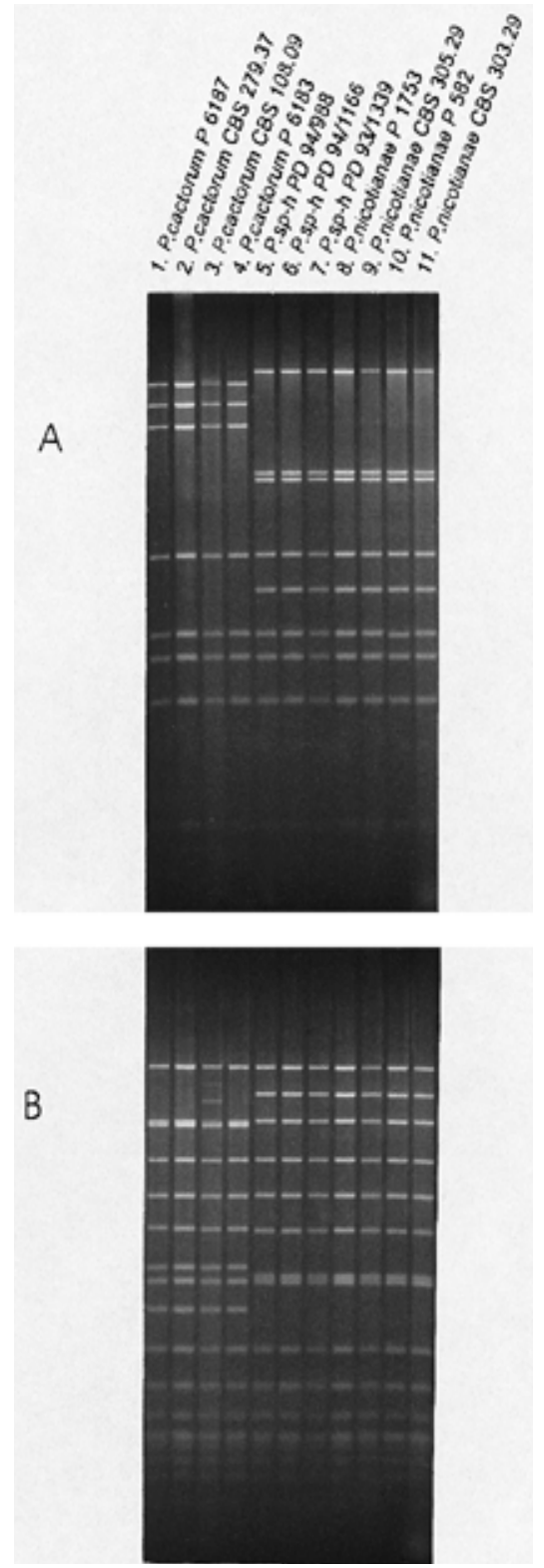

Fig. 4. Banding patterns of mitochondrial DNA digested with A, HindII and B, ScrfI. 
$M d h-2^{93}$ alleles of $P$. cactorum. Both enzymes are known to be dimeric $(15,18)$; consequently, two homodimeric bands and one intermediate heterodimeric band at both enzyme loci should be present in Phytophthora sp-h strains (10). Oudemans and Coffey $(19,20)$ found the MDHP and MDH enzyme patterns to be consistent within 47 P. cactorum isolates and within 60 P. nicotianae isolates. They found two Mdhp alleles in P. nicotianae, whose gene products, however, comigrate in our gel system (data not shown).

The three-banded pattern at $M d h-2$ of $P$. iranica was interpreted as heterozygous; the faint upper band was hypothesized to be caused by so-called null allelism. Null alleles produce faint, or not visible, homodimeric bands, but strong heterodimeric bands (21). If this interpretation is correct (fixed heterozygosity through tandem gene duplication might be an alternative explanation), this is peculiar, considering the homothallic nature of $P$. iranica. Homothallic species should be homozygous after constant selfing.

Since hybrids are difficult to detect, it is not clear whether interspecific hybridization in Phytophthora is a common event in nature. As noted before by Brasier (2), it is not very likely that hybrids will be detected by orthodox taxonomy, since, because of their appearance, they will be labeled as atypical representatives of a species or as unidentified. Indeed, based on cultural characters, it is not possible to detect the hybrid nature of the three Phytophthora $\mathrm{sp}$-h strains nor to assign their putative parents unambiguously.

Only mtDNA of $P$. nicotianae was found in the hybrids described here (Fig. 4A and B), confirming the parenthood of $P$. nicotianae. Apparently, $P$. nicotianae has acted as the oogonial strain in all three hybrid strains.

Interspecific hybridization has been reported for a few other species of Phytophthora only. Boccas (1) attempted to cross different Phytophthora species, and out of 220 progeny, he regarded one as an interspecific hybrid between $P$. capsici and $P$. palmivora, as deduced from general protein patterns; in all other cases, oospores, presumed to be the result of interspecific hybridization, were concluded to be the result of selfing.

Two genetic forms (polyploid and diploid) of $P$. meadii are known to exist. Based upon the observation that the diploid form of $P$. meadii produced small oogonia, which degenerated during meiosis resulting in many empty oogonia, Sansome et al. (22) concluded that the diploid form of $P$. meadii might represent a species hybrid.

Brasier et al. (3) speculated upon a hybrid nature of isolates belonging to group $\mathrm{O}$ (unknown taxa), which have similarities to $P$. gonapodyides and P. cryptogea with respect to morphology and general protein patterns.

Goodwin and Fry (9) crossed the closely related $P$. infestans and $P$. mirabilis, both having a limited host range. Isozyme analysis proved that 79 out of 86 progeny were interspecific hybrids. DNA fingerprint analysis confirmed the hybrid nature of the strains created. Most of the hybrids had lost the ability to infect the hosts that were infected by the parents.

Érsek et al. (6) created interspecific hybrids between $P$. capsici and $P$. nicotianae by zoospore fusion. This was confirmed by the occurrence of DNA sequences unique to both $P$. capsici and P. nicotianae in the putative hybrids. In contrast to the results of Goodwin and Fry (9), some hybrids created by Érsek et al. (6) had expanded host ranges.

Except for the putative hybrid nature of the diploid form of $P$. meadii and isolates belonging to group $\mathrm{O}$ (22), all hybrids reported in literature are laboratory made. The isolates described in the current paper seem to be the first reported hybrids of natural origin.

Since the introduction of hydroponic systems in greenhouses in the Netherlands, an increase of Phytophthora outbreaks has been recorded. In many greenhouses, different crops are serviced by the same hydroponic system and, hence, different Phytophthora species, colonizing different hosts, can be present simultaneously in the hydroponic system. Hybrids could have been formed by anastomosis or through interspecific mating. The latter requires that the homothallic $P$. cactorum has served as the opposite mating type, since $P$. nicotianae is heterothallic. Stephenson et al. (27) showed that hyphal anastomosis occurs in $P$. capsici. Outcrossing has not been demonstrated before for $P$. cactorum. However, it has been shown by Whisson et al. (29) that, in homothallic isolates of $P$. sojae, outcrossing can occur.

Artificial inoculation of Spathiphyllum plants with PD 93/1339 and PD 94/1166 in hydroponic systems caused the same symptoms (blackening of stems) with which the hybrids originally were associated (A. Kerssies and A. Numansen, personal communication). After reisolation (six reisolations), the fungus showed the same isozyme patterns (Fig. 2A and B, lanes 4 to 7) and morphology as the isolates that were used for the infection, thus confirming the postulates of Koch.

Oospores were observed in the stems of diseased Spathiphyllum plants. At this moment, it is not clear whether they are fertile.

The hybrids described in this paper probably survived vegetatively after formation, through chlamydospores and as mycelium in infected plant tissue.

The intraspecific consistency of both $P$. nicotianae and $P$. cactorum indicates that they are well defined and distinct species (19, 20). The existence of hybrids between the two species suggests that they recently derived from a common ancestor. Based on ITS sequences, Cooke and colleagues $(4,5)$ concluded that $P$. nicotianae is closely related to $P$. cactorum. In the course of evolution, the two species diverged, but their divergence apparently has not yet reached the phase at which the two genomes are no longer compatible.

The phytopathological and taxonomical consequences of interspecific hybridization in Phytophthora are not yet fully understood. When using molecular markers for identifying isolates of Phytophthora spp. (e.g., restriction enzyme analysis of mtDNA), one should be aware of the possible occurrence of hybrid forms.

In view of the change in host specificity of Phytophthora hybrids compared with their parental strains $(6,9)$, interspecific hybridization might be an important means of extension of host ranges or exploration of new hosts in Phytophthora and, thus, in the rapid evolution of new species.

\section{ACKNOWLEDGMENTS}

We thank M. Coffey for his generous gift of some Phytophthora nicotianae and P. cactorum isolates, and $\mathrm{H}$. de Gruyter and G. Karssen for critically reading the manuscript. We thank J. de Cock, T. de Haas, and T. van den Bosch for skillful technical assistance. We also thank P. Sassen and R. Wolbert for their stimulating discussions.

\section{LITERATURE CITED}

1. Boccas, B. R. 1981. Interspecific crosses between closely related heterothallic Phytophthora species. Phytopathology 71:60-65.

2. Brasier, C. M. 1991. Current questions in Phytophthora systematics. Pages 104-128 in: Phytophthora. Cambridge University Press, Cambridge.

3. Brasier, C. M., Hamm, P. B., and Hansen, E. M. 1993. Cultural characters, protein patterns and unusual mating behaviour of Phytophthora gonapodyides isolates from Britain and North America. Mycol. Res. 97: 1287-1298.

4. Cooke, D. E. L., and Duncan, J. M. 1997. Phylogenetic analysis of Phytophthora species based on ITS1 and ITS2 sequences of the ribosomal RNA gene repeat. Mycol. Res. 101(6):667-677.

5. Cooke, D. E. L., Kennedy, D. M., Guy, D. C., Russell, J., Unkles, S. E., and Duncan, J. M. 1996. Relatedness of group I species of Phytophthora as assessed by random amplified DNA (RAPDs) and sequences of ribosomal DNA. Mycol. Res. 100(3):297-303.

6. Érsek, T., English, J. T., and Schoelz, J. E. 1995. Creation of species hybrids of Phytophthora with modified host ranges by zoospore fusion. Phytopathology 85:1343-1347.

7. Ershad, D. 1971. Beitrag zur Kenntnis der Phytophthora Arten in Iran und ihrer Phytopathlogischen Bedeutung (Contribution to the knowledge of Phytophthora species in Iran and their phytopathogenic importance). Mitt. Biol. Bundesanst. Land Forstwirtsch. Berl. Dahlem 140.

8. Gams, W., van der Aa, H. A., van der Plaats-Niterink, A. J., Samson, R. A., and Stalpers, J. A. 1987. CBA Course of Mycology. CBS (Centraalbureau voor Schimmelcultures) Institute, Baarn, the Netherlands. 
9. Goodwin, S. B., and Fry, W. E. 1994. Genetic analysis of interspecific hybrids between Phytophthora infestans and Phytophthora mirabilis. Exp. Mycol. 18:20-32.

10. Goodwin, S. B., Webster, R. K., and Allard, R. W. 1994. Evidence for mutation and migration as sources of genetic variation in populations of Rhynchosporium secalis. Phytopathology 84:1047-1053.

11. Hamm, P. B., and Hansen, E. M. 1983. Phytophthora pseudotsugae a new species causing root rot of Douglas-fir. Can. J. Bot. 61:2626-2631.

12. Kennedy, D. M., and Duncan, J. M. 1995. A papillate Phytophthora species with specificity to Rubus. Mycol. Res. 99:57-68.

13. Klassen, G. R., Balcerzak, M., and de Cock, A. W. A. M. 1996. 5S ribosomal RNA gene spacers as species-specific probes for eight species of Pythium. Phytopathology 86:581-587.

14. Kröber, H. 1985. Erfahrungen mit Phytophthora de Bary und Pythium Pringsheim. Mitt. Biol. Bundesanst. Land Forstwirtschaft. Berl. Dahlem 225.

15. Manchenko, G. P. 1988. Subunit structure of enzymes: Allozymic data. Isozyme Bull. 12:144-158.

16. Möller, E. M., Bahnweg, G., Sandermann, H., and Geiger, H. H. 1992. A simple and efficient protocol for isolation of high molecular weight DNA from filamentous fungi, fruit bodies, and infected plant tissues. Nucleic Acids Res. 20:6115-6116.

17. Möller, E. M., de Cock, A. W. A. M., and Prell, H. H. 1993. Mitochondrial and nuclear DNA restriction enzyme analysis of the closely related Phytophthora species P. infestans, P. mirabilis, and P. phaseoli. J. Phytopathol. 139:309-321.

18. Mosa, A. A., Kobayashi, K., Ogoshi, A., Kato, M., and Sato, N. 1993. Isoenzyme polymorphism and segregation in isolates of Phytophthora infestans from Japan. Plant Pathol. 42:26-34.

19. Oudemans, P., and Coffey, M. D. 1991. Isozyme comparison within and among worldwide sources of three morphologically distinct species of Phytophthora. Mycol. Res. 95:19-30.

20. Oudemans, P., and Coffey, M. D. 1991. A revised systematics of twelve papillate Phytophthora species based on isozyme analysis. Mycol. Res. 95:1025-1046.

21. Richardson, B. J., Baverstock, P. R., and Adams, M. 1986. Electrophoresis. Page 23 in: Allozyme Electrophoresis. Academic Press, New York.

22. Sansome, E., Brasier, C. M., and Hamm, P. B. 1991. Phytophthora meadii may be a species hybrid. Mycol. Res. 95:273-277.

23. Southern, E. M. 1975. Detection of specific sequences among DNA fragments separated by gel electrophoresis. J. Mol. Biol. 98:503-517.

24. Spielman, L. J., Sweigard, J. A., Shattock, R. C., and Fry, W. E. 1990. The genetics of Phytophthora infestans: Segregation of allozyme markers in F2 and backcross progeny and the inheritance of virulence against potato resistance R2 and R4 in F1 progeny. Exp. Mycol. 14:57-69.

25. Stamps, D. J., Waterhouse, G. M., Newhook, F. J., and Hall, G. S. 1990. Revised tabular key to the species of Phytophthora. Mycol. Pap. No. 162. International Mycological Institute, Kew, United Kingdom.

26. Stenlid, J., Karlsson, J. O., and Högberg, N. 1994. Intraspecific genetic variation in Heterobasidion annosum revealed by amplification of minisatellite DNA. Mycol. Res. 98:57-63.

27. Stephenson, L. W., Erwin, D. C., and Leary, J. V. 1974. Hyphal anastomosis in Phytophthora capsici. Phytopathology 64:149-150.

28. Waterhouse, G. M. 1963. Key to the species of Phytophthora de Bary. Mycol. Pap. No. 92. International Mycological Institute, Kew, United Kingdom.

29. Whisson, S. C., Drenth, A., Maclean, D. J., and Irwin, J. A. G. 1994. Evidence for outcrossing in Phytophthora sojae and linkage of a DNA marker to two avirulence genes. Curr. Genet. 27:77-82. 